\title{
The relationship between family emotional climate with emotional self-regulation and resilience in university's students
}

\author{
Fereshteh Saberi Fard ${ }^{1}$, Fatemeh Hajiarbabi ${ }^{2}$ \\ 1-Master of Consultation, Joyandegan saadat mental healt center, Islamic azad university neyshabur branch, \\ Neyshabur, Iran. ORCID: 0000-0001-9990-9430 \\ 2-Assistant professor, Psychology, Kavian institute of higher education, Mashhad, Iran (Corresponding Author). \\ ORCID: 0000-0002-8878-9215_E-mail: Arbabi.f777@yahoo.com
}

Recei ved: 09/10/2018

Acce pted: 12/01/2019

\section{Abstract}

Introduction: Identifying the factors related with the affective family climate are among the most important family psychological research goals.

Aim: This study was conducted with the aim of examining the relationship of affective family climate with emotional self-regulation and resiliency of students. The statistical population of this research consisted of all the students of Azad University of Mashhad who were busy studying during the educational year of 2017-2018.

Method: The method of this research was descriptive of correlational type. The research sampling was done using stratified sampling and included 150 students. Research instrument consisted of three questionnaires of affective family climate (Hill Berne, 1964), emotional selfregulation questionnaire (Hoffman and Kashdan, 2010) and resiliency questionnaire (Cutter and Davidson, 2003). The data were analyzed using Pearson correlation test and multivariate regression.

Results: The findings showed that, affective family climate is significantly correlated with emotional self-regulation and resiliency $(\mathrm{P}<0.05)$.

Conclusion: According to the findings, it can be stated that, regulation of emotions and resiliency are two important variables that are associated with the affective family climate in the students.

Keywords: Affective family climate, Emotional self-regulation, Resiliency, Students

How to cite this article : Saberi Fard F, Haiiarbabi F. The relationship between family emotional climate with emotional self-regulation and resilience in university's students. Shenakht Journal of Psychology and Psychiatry. 2019; 6 (1): 49-63 .URL :http://shenakht.muk.ac.ir/article-1558 -fa.pdf

Copyright (C) 2018 the Author (s). Published by Kurdistan University of Medical Sciences. This is an open access article distributed under the terms of the Creative Commons Attribution-Non Commercial License 4.0 (CCBY-NC), where it is permissible to download, share, remix, transform, and buildup the work provided it is properly cited. The work cannot be used commercially without permission from the journal. 


\title{
رابطه جو عاطفى خانواده با خود تنظيمى هيجانى و تاب آورى در دانشويان دانشكاه آزاد مشهد
}

\author{
فرشته صابرى فرد'، فاطمه حاجى اربابى \\ 1. كارشناسى ارشد مشاوره، مركز سلامت روان جويند كان سعادت، دانشكاه آزاد اسلامى واحد نيشابور، نيشابور، اير ان.

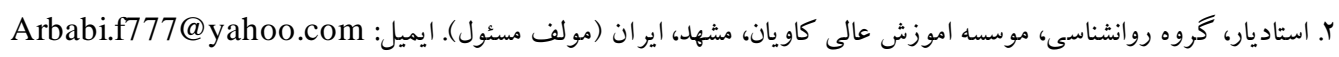

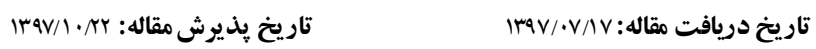

جكيده

مقدمه: شناسايى عو امل مرتبط با جو عاطفى خانو اده از مهمترين اهداف يزوهشى روانشناسى خانو اده است. هدف: اين يُزوهش با هدف بررسى رابطه جو عاطفى خانواده با خود تنظيمى هيجانى و تاب آورى دانشجويان انجام گرفت. جامعه

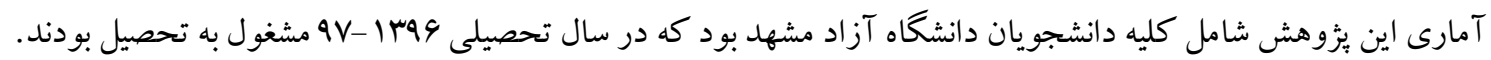

10. روش: روش اين ئزوهش، توصيفى از نوع همبستگى بود. نمونه يزوهش با روش نمونه گيرى طبقهاى انجام يذيرفت و شامل

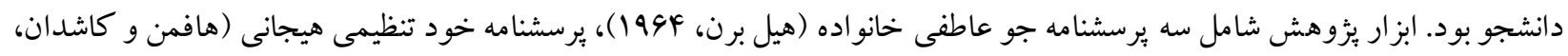

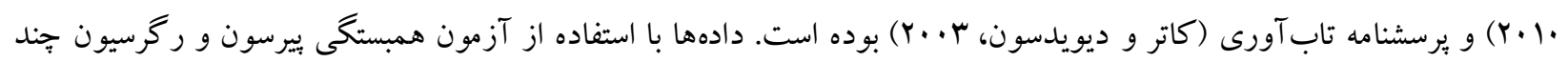

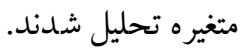
يافته ها: يافتهها نشان داد، جو عاطفى خانو اده با خودتنظيمى هيجانى و تابآورى ارتباط معنادارى دارد (ه •/P> (P). نتيجه كيرى: با توجه به يافتها مىتوان كفت، تنظيم هيجانات و تابآورى دو متغير مهمى هستند كه با جو عاطفى خانو اده در

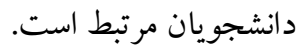
كليد وازه ها: جو عاطفى خانو اده، خودتنظيمى هيجانى، تاب آورى، دانشجويان 
اجتماعى - اقتصادى مى تو ان والدينى را بيدا كرد كه به علت بىثباتى شخصيتى به طريقى با مردم رفتار مى كنند كه براى آنها مخرب است، همان گونه كه براى خود

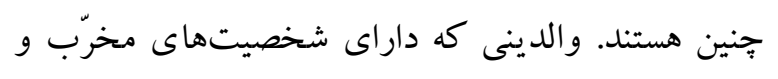
غيرعادى هستند، ممكن است خانه را در يك اضطراب

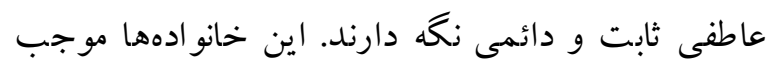

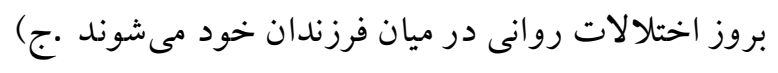

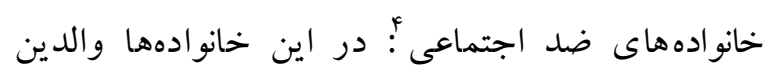
بهطور آشكار يا نهان رفتارى را نشان مى دهند كه مغاير

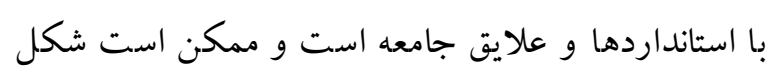
نادرستى را در برخورد با قانون بيدا كند. جنين ارزشهاى

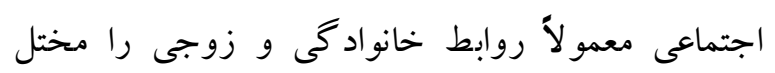
مى كند و مدلهاى نامعقول را براى بجيه فراهم مى كند.

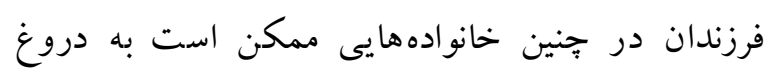
كفتن و تقلب و رفتارهاى نامعقول ديخر تشويق شوند. د)

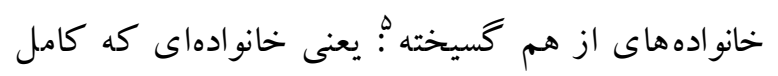
نيست، جه در نتيجه طلاق يا شرايط ديخر (نجاريور

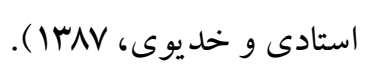

حال با توجه به تيبهاى مختلف در جو خانواده، مى توان

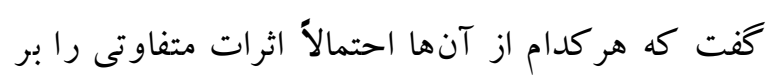
بروندادهاى رفتارى، هيجانى و شناختى فرزندان و اعضاى آن آنا آن مى گذراند. يزوهشهايى نشان دادهاند كه جو عاطفى رهي خانواده يك عامل مهم در شكل گيرى هيجانات افراد خانو اده و ميزان تحمل آنها در مقابل فشارهاى روانى و و

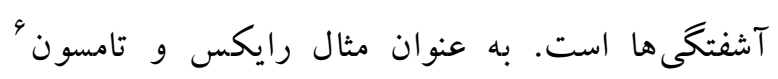
(Y..9) خانو اده مى تواند عاملى جهت بيش بينى دانش هيجانى

\footnotetext{
${ }^{4}$ antisocial family

${ }^{5}$ disrupted family

${ }^{6}$ Raikes, \& Thompson
}

مقل مه

يكى از نهادهاى اوليه در نظام انسانى، خانواده است. به

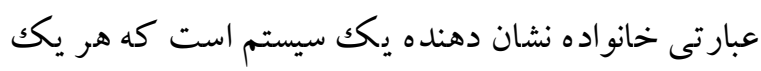
از اعضاى آن نسبت به ديخرى داراى وظايفى هستند

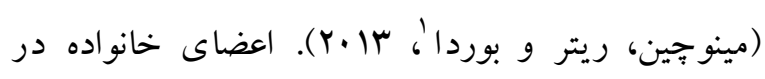
نهايت داراى نقشهايى مىشوند كه الكوهاى رفتارى آنها متأثر از كذشته و تحولهايى بوده است كه در سيستم خانواده بوده است. يكلى از عضوهاى مهم خانواده فرزندانى هستند كه وارد دانشگاه مىشوند و به تحصيل

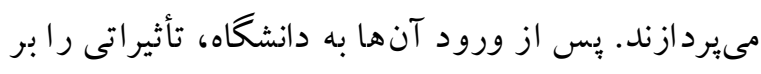
كروه دوستان مى گذراند و از طرفى نيز تأثير مى بذيرند.

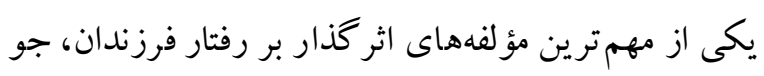
عاطفى خانو اده است. براى اينكه وظايف اصلى خانواده يعنى حمايت از فرديت يابى و در عين حال حس تعلق بين اعضاء خانواده و همجنين بيرون از خانواده ايجاد شود، خانواده بايد داراى ساخت كار آمد و خود كفايى

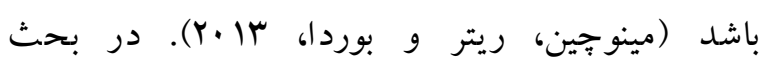
تيبش شناسى خانو ادهها مى تو ان جهار نمونه ر ا مورد بررسى لونى قرار داد: - ماد

الف) خانواده بى كفايت ب؛ اين خانوادهها نمىتوانند از عهده مقابله با مسائل معمولى كه در زندكى خانوادكى

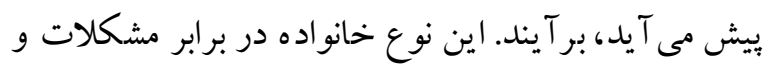

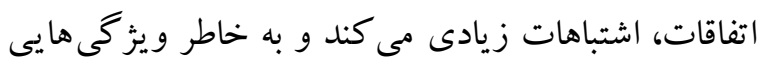
كه داراست، دجار مشكلات زيادى مى گر دد و نمى تو اند به كود كان خود احساس سلامت و امنيت بدهد، يا اينكه نمىتو اند يك راهنماى كافى براى رشد شايستخىهاى ضرورى آنها باشد .ب) خانواده آشفته ؛ّ در هر سطح

\footnotetext{
${ }^{1}$ Minuchin, Reiter, \& Borda

${ }^{2}$ inadequate family

${ }^{3}$ disturb family
} 
هشيار و ناهشيار روانشناختى، رفتارى و شناختى را در

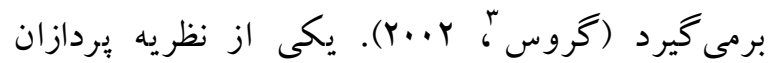
مطرح در اين زمينه به نام گروس (1991) اعتقاد دارد كه هيجانات مىتوانند تغيير كند و اين تغيير جيزى است كه ياسخ عاطفى نهايى را تعيين مى كند.

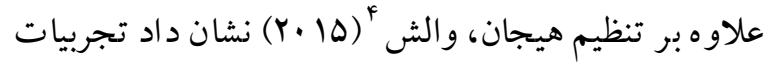
تجربيات درون خانوادكى با تابآورى ارتباط دارد؛ بنابراين متغير دوم مورد بررسى جهت ارتباط با جو عاطفى خانواده، تابآورى است. ماستن، كو تلى، هربر و

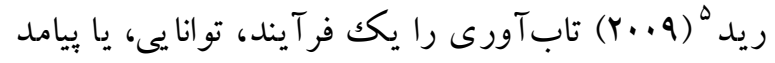

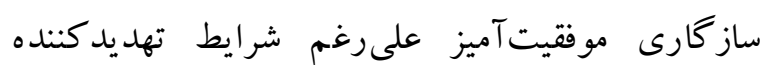
تعريف نمودهاند در واقع تابآورى ساز گارى مثبت در

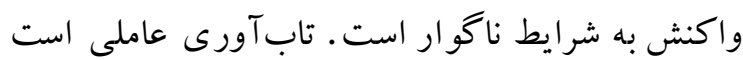
كه باعث انعطاف يذيرى و مقابلة مؤثر با عوامل و و

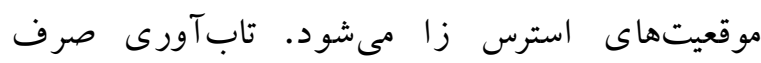
مقاومت منفعل در برابر آسيبها يا شرايط تهديدكننده نيست. بلكه فرد تاب آور، مشاركت كننده فعال و سازنده محيط بيرامونى خود است. تابآورى قابليت فرد در برقرارى تعادل زيستى - روانى - معنوى، در مقابل شرايط

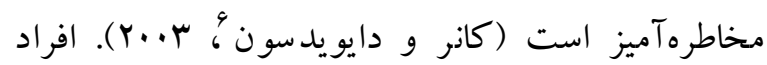
خود تاب آور داراى رفتارهاى خودشكنانه نيستند؛ از نظر عاطفى آرام هستند و توانايى تبديل شرايط استرسزا را دارند (بلا كك و فوندر، ه ·.r، به نقل از نريمانى و عباسى، .$(1 \mathrm{MM}$

در زمينه، ارتباط جو عاطفى خانو اده، خود تنظيمى هيجانى و تابآورى ئزوهشهايى انجام شده است. عباسى،

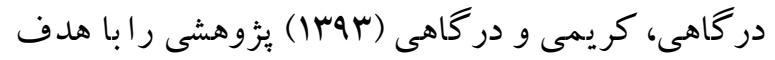

${ }^{3}$ Gross

${ }^{4}$ Walsh

${ }^{5}$ Masten, Cutuli, Herbers,\& Reed

${ }^{6}$ Conner, \& Davidson
كود كان آن خانو اده باشد. علاوه بر آن هالتبر گى، هنرى و

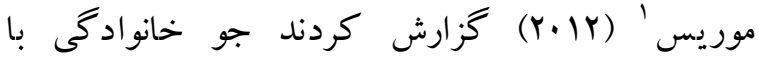
تابآورى و تحمل افراد خانواده ارتباط نزديكى دارد. ״س بر همين اساس متغيرهاى مورد بررسى جهت ارتباط با جو عاطفى خانو اده در اين بثروهش خودتنظيمى هيجانى

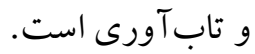
نتايج بزوهشها حاكى از آن است كه محيط خانواده با خود تنظيمى هيجانى ارتباط دارد (تروسير، بازلا، بنت و و

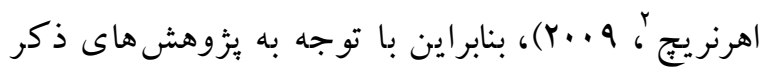

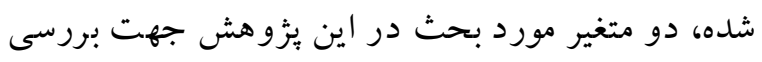
ارتباط آنها با جو عاطفى خانو اده، تنظيم هيجان و تابآورى است. منظور از مهارت تنظيم هيجان اين است

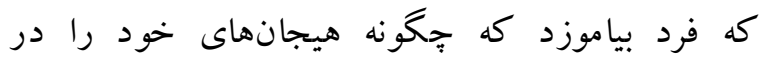
موقعيتهاى گوناگون تشخيص دهد و آن را ابراز يا كنترل كند؛ به عبارت ديخر دشوارى تنظيم هيجانى عبارت است از دشوار بودن يا ناممكن بودن مقابله با تجربه هيجان و يا بردازش آن. دشوارى تنظيم هيجانى مى تواند به صورت تشديد بيش از حد هيجان و يا غير فعال شدن بيش از حد هيجان تظاهر كند. تشديد بيش از حد هيجان شامل هر گونه افزايش در شدت هيجان است كه فرد مربوطه آن را ناخواسته، مزاحم، مستأصل كننده، يا دردسرساز مىانگًارد (لى هى و نايوليتانو،

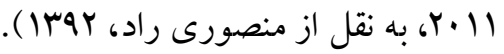
استراتزىهاى تنظيم هيجان بر رشد شخصيتى، هيجانى، شناختى و اجتماعى دلالت دارند. وقتى اين عوامل تحت

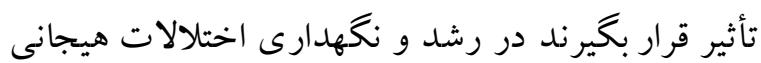
نقش بر جستهاى ايفا مى كنند. در حقيقت مفهوم تنظيم

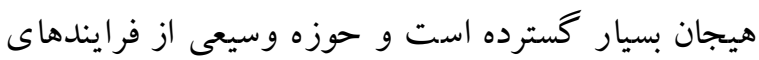

\footnotetext{
${ }^{1}$ Houltberg, Henry, \& Morris

${ }^{2}$ Trosper, Buzzella, Bennett \& Ehrenreich,
} 
جو عاطفى آن مكانى است جهت آماده سازى كود كان براى رو به رو شدن با جالشهاى آينده آنها. يولكى،

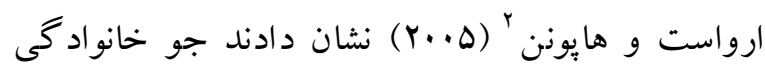
ييش بينى كننده ر اهبردهاى تاب آورى در خانو اده است. همجِنين آن ها استنباط كردند كه جو خانواد كى بيش بينى كننده راهبردهاى مقابله با استرس در آينده براى كودكان است. علاوه بر آن مىتوان نتيجه گرفت كه با لبا مداخله در خانو اده مىتوان مشكلات و بيمارى هاى افراد خانو اده را به طور معناد ارى كاهش داد. با توجه به بيان مسئله، ئزوهشها نشان داده بودند كه بين تابآورى، تنظيم هيجانى و جو عاطفى خانواده ارتباط

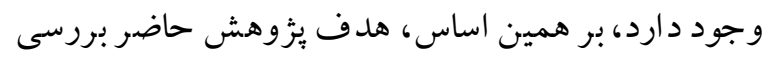
ارتباط جو عاطفى خانواده با خودتنظيمى هيجانى و و تابآورى بود. اين ئزوهش داراى سه فرضيه بود كه به

$$
\text { شرح زير است؛ }
$$

فرضيه اول: بين جو عاطفى خانو اده و مؤلفههاى آن و و

خود تنظيمى هيجانى و مولفه هاى آن رابطه وجود دارد. فرضيه دوم: بين جو عاطفى خانو اده و مؤلفه هاى آن و تاب آورى رابطه وجود دارد.

فرضيه سوم: جو عاطفى خانو اده مىتواند خودتنظيمى هيجانى و تاب آورى را بيش بينى كند

\section{روش}

با توجه به ماهيت موضوع و اهدافى كه تحقيق دنبال مى كرد، يزوهش حاضر از نظر روش تحقيق يك تحقيق توصيفى از نوع همبستكى محسوب مى شود و از حيث هدف در زمره يزوهشهاى بنيادى قرار دارد كه در آن
بررسى روابط خانوادگى، كيفيت زند گى و تابآورى بين د انش آموزان مبتلا به اختلال نقص تو جه / بيش فعالى رئى

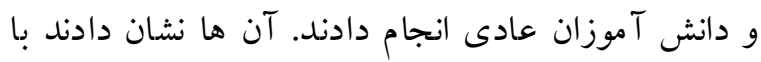
توجه به روابط خانو ادكى بهتر مى تو ان كيفيت زندگى و و تابآورى را در اختلال بيش فعالى بيش بينى كرد.

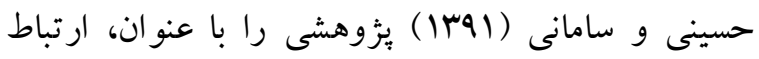
ابعاد كاركرد خانواده و خودتنظيمى فرزندان، انجام دادند. يافتهها نشان دادند كه ياسخدهى عاطفى بيشبينى كننده فراشناخت فرزندان بود و نقش ها قابليت بيشبينى شناخت فرزندان را دارد، همجزين كاركرد هيجانى خانو اده بيشبينى كننده انگيزش فرزندان است. همبحنين، خداجوادى و همكاران (·ara) يثوهشى را با عنوان، رابطه كاركرد خانو اده و تابآورى در برابر مصرف مواد در دانش آموزان يسر دبيرستانى مدارس يرخطر انجام دادند. نتايج آنها نشان داد، ياسخدهى عاطفى خانو اده با

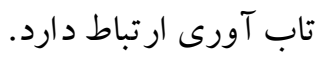

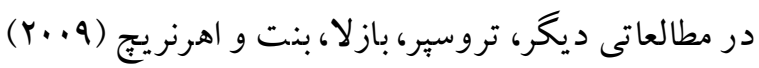
نشان دادند بين جو خانوادگى و تنظيم هيجانى ارتباط وجود دارد. همجنين آن ها نتيجه كرفتند كه مىتوان با ليا توجه به جو عاطفى خانواده و آموزشهاى مهارت هاى خودتنظيمى هيجانى، عملكرد فرد را افزايش داد و و وله همجنين مى توان از اختلالات روانى همجون اضطراب و و استرس بيشخيرى كرد. آماتيا، اسميت -آدكوكى و و

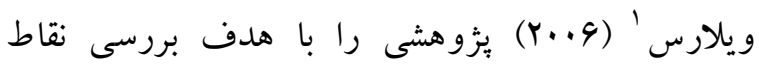
ضعف و قوت خانواده در تبيين تابآورى در كودكان خانواده انجام دادند. آنها در بُزوهش خود كز ارش كردند نقص خانو ادكى مىتو اند تاب آورى را كاهش دهد. در واقع نتايج آنها گوياى اين بود كه خانواده و 
ابزار برسشنامه جو عاطفى خانوادة: اين مقياس توسط هيل برن (1994) به منظور سنجش ميزان مهرورزى در تعاملات

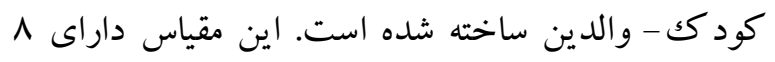
خرده مقياس (محبت، نوازش كردن، تجربههاى مشتر كى، هديه دادن، تشويق، اعتماد و احساس امنيت)، است. كل

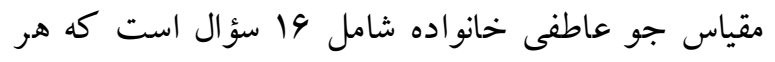

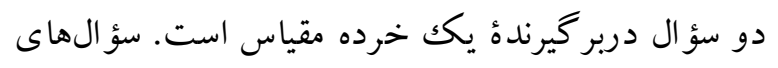

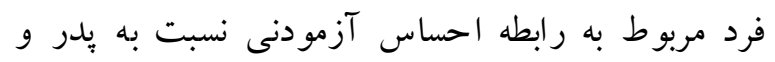

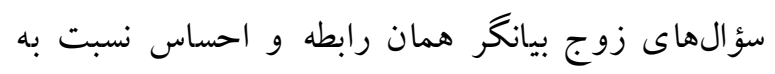

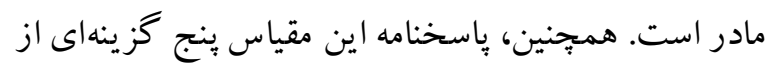

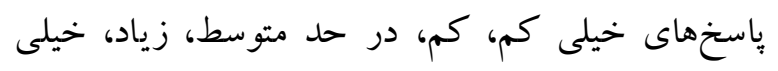
زياد، تشكيلشده است كه آزمودنى بر حسب احساس

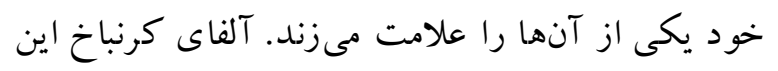

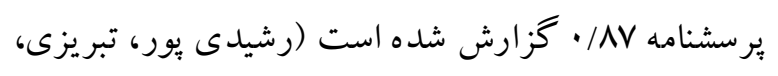

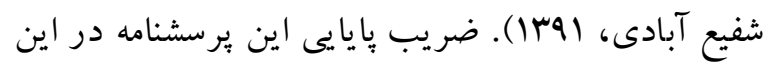

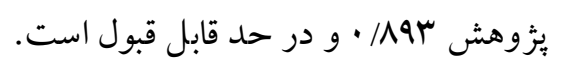

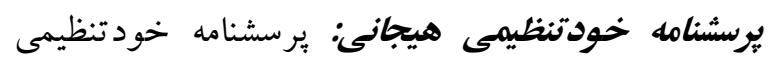

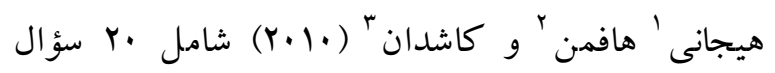
است؛ كه هاسخكويى به آنها بر اساس طيف ليكرت هـ

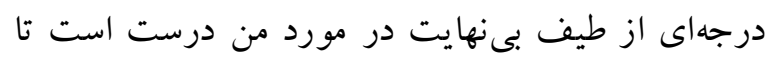
اصلاً در مورد من درست نيست را شامل مىشود.

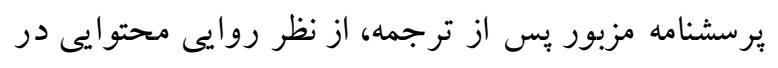

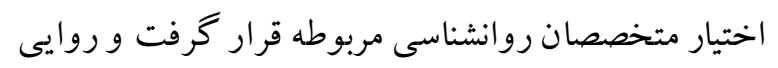
محتوايى آن تائيد شد. يرسشنامه داراى سه مؤلفه يا روائا خورده مقياس بنهان كارى، سازش كارى و تحمل است

\footnotetext{
${ }^{1}$ emotional self-regulation

${ }^{2}$ Hofmann

${ }^{3}$ Kashdan
}

رابطه خود تنظيمى هيجانى و تابآورى با جو عاطفى خانو اده در دانشجويان بررسى شد. جامعهى آمارى اين يُروهش شامل دانشجويان مشغول به به بهر

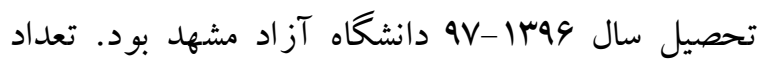
اين دانشجويان حدود rا هزار نفر بود. دامنه سنى دانشجويان مورد مطالعه بين 1 التا ·r سال بود و همجينين مقطع تحصيلى آنها كارشناسى و كارشناسى ارشد بود. در اين يُووهش با توجه به حجم بزركى جامعه آمارى

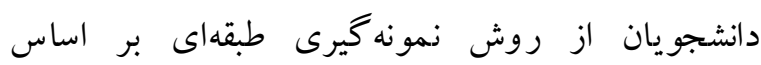

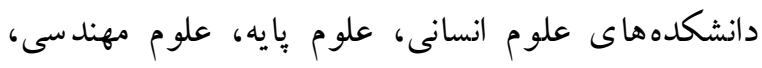

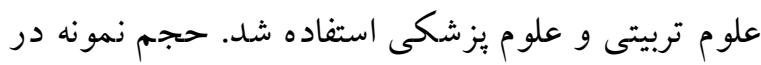

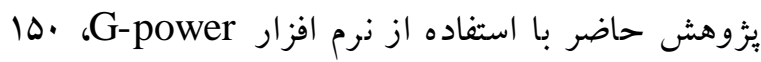

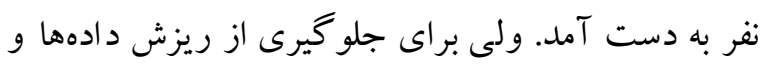

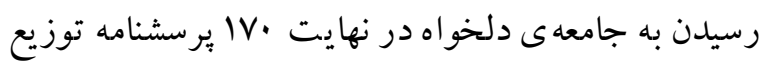
كرديد. دلايل انتخاب روش نمونه گيرى طبقهاى شامل: هزينه اجرا، بالا رفتن سرعت إزوهشكر، كسب آنساب

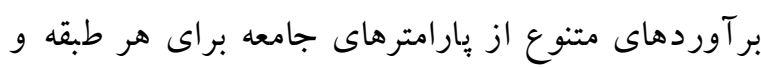
دقت بالا در شناسايى تغيير بذيرى هر طبقه نسبت به به بهائ

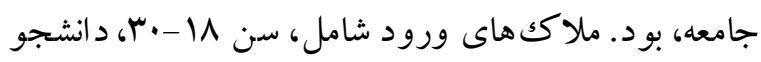

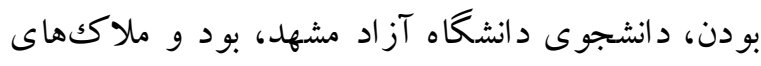

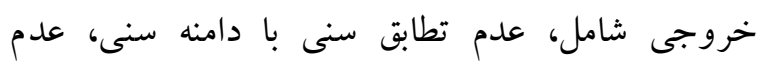

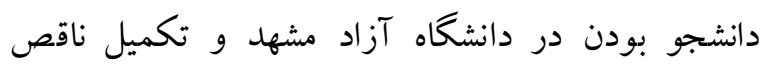
بر سشنامه ها، بود. يرسشنامهاى اين يزوهش كه حاوى نكات لازم در برد

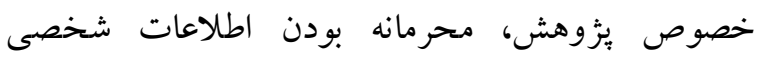
آزمودنىها و مشخصات فردى بود به تعداد مورد نياز تهيه

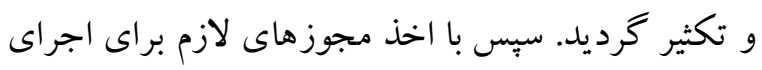
IV. يزوهش به همراه احتساب حجم نمونه، تعداد ير سشنامه در بين دانشجويان توزيع گرديد. 


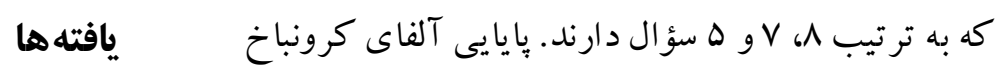
نرم افزار مورد استفاده در اين يثوهش هو

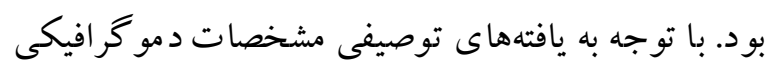

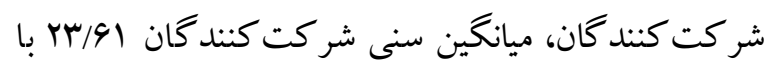

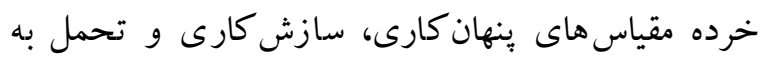

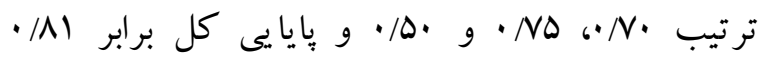

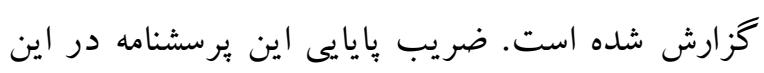

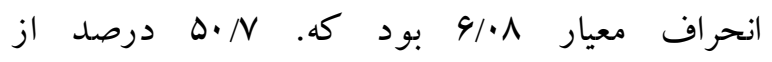
يثزوهش AYV • • و در حد قابل قبول است.

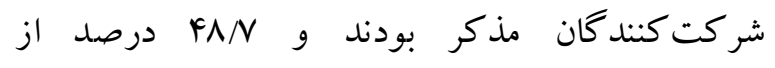
يرسشنامه تابآورى: اين يرسشنامه را كانر و ديو يدسون شركت كنند كان مؤنث بودند.،

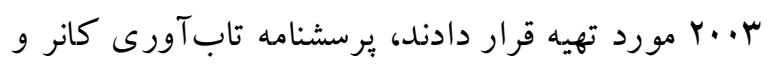

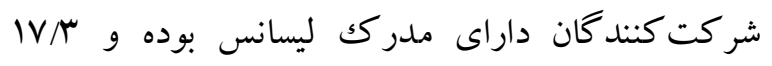
درصد از آن ها داراى مدركك فوق ليسانس بودند. از لحاظ شغلى، VY/V درصد از شركت كنند كان شاغل و YG/N

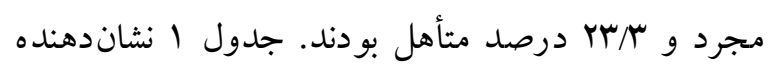
شاخصهاى توصيفى جو عاطفى خانو اده است. ديويدسون هY گويه دارد كه در يكك مقياس ليكرتى بين صفر (كاملاً نادرست) و ينج (هميشه درست) نمره كذارى مى شود. سامانى، جو كار و صحراكرد ( يثزوهشى به بررسى روايى و بِايايى اين مقياس را در

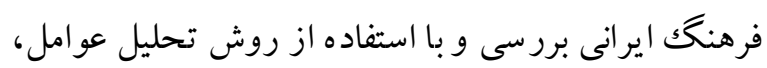

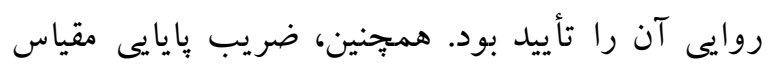

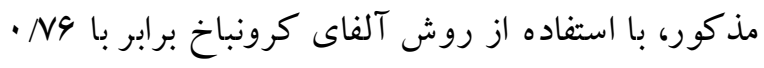
كزارش شده است. ضريب بايايى اين بِرسشنامه در اين يزوهش MAY/ • و در حد قابل قبول است.

\begin{tabular}{|c|c|}
\hline ميانكين /انحر اف معيار & متغير \\
\hline $1 / 94 / V / 9 V$ & محجبت \\
\hline$r / 1 \cdot / 9 / 4$. & 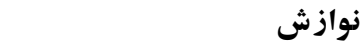 \\
\hline I/VA / G/N & تائيد كردن \\
\hline$r / r F / 9 / .9$ & تجربه هاى مشتر كى \\
\hline$r / r \cdot / 9 / 9 V$ & هديه دادن \\
\hline$r / 19 / 9 / 91$ & تشويق كردن \\
\hline $\mathrm{r} / \Lambda / \mathrm{V} / \mathrm{r}$. & اعتماد \\
\hline $1 / 9 F / V / V F$ & احساس امنيت \\
\hline$V / r \cdot / r q / I F$ & مادر -فرزندى \\
\hline $9 / 00 / r q / 19$ & يدر -فرزندى \\
\hline $\mid r / r \cdot / \Delta \Delta / r \Delta$ & نمره كل جو عاطفى خانواده \\
\hline$\Delta / M F / Y Y / M F$ & ساز كارى \\
\hline$F / 9 \Lambda / r 1 / 99$ & 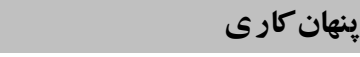 \\
\hline$r / 9 \cdot / I r / r Y$ & تحمل \\
\hline
\end{tabular}




\begin{tabular}{|c|c|}
\hline $11 / 49 / 95 / 91$ & نمره كل خودتنظيمى هيجانى \\
\hline $1 \Delta / \Delta / \Delta Q / \Lambda F$ & تاب آورى \\
\hline
\end{tabular}

فرضيه اول: بين جو عاطفى خانو اده و مؤلفه هاى آن و خود تنظيمى هيجانى و مؤلفه هاى آن رابطه وجود دارد.

جدول r ضريب همبستكى ييرسون بين خودتنظيمى هيجانى و جو عاطفى خانواده

\begin{tabular}{|c|c|c|c|c|}
\hline نمره كل & تحمل & ينهان كارى & ساز Fارى & متغير \\
\hline$-\cdot 1 \cdot r_{4}$ & $-\cdot / \cdot Y_{1}$ & $-\cdot / \cdot r r$ & $\cdot / \cdot F \wedge$ & محبتت \\
\hline$-\cdot / \cdot \Delta \Delta$ & $-\cdot / 11 r$ & $-\cdot / \cdot v^{4}$ & $\cdot / \cdot \sqrt{ } 1$ & 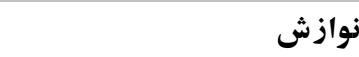 \\
\hline .11 .9 &.$- / \cdot r t$ & $-\cdot / \cdot \Delta$ & $* * \cdot / r \cdot \Lambda$ & تائيد كردن \\
\hline$-\cdot / \cdot r)$ &.$- / .01$ & $*=\cdot / r \cdot \Lambda$ & $* \cdot / 19 \mu$ & تجربه هاى مشتر كى \\
\hline$-\cdot / l f$. & * $=\cdot /$ rr & $* \cdot / M r$ & .1 .94 & هديه دادن \\
\hline$-\cdot / \cdot 11$ & $-\cdot / I Y F$ & $-\cdot / 1 Y \Delta$ & $\cdot / 141$ & تشويق كردن \\
\hline$\cdot / \cdot r V$ & $-\cdot / 1 \cdot 1$ & $-\cdot / \cdot \Delta V$ & $* \cdot 199$ & اعتماد \\
\hline$-\cdot / 1 F q$ & $-\cdot / \mathrm{kr}$ & $* \cdot / \wedge \Delta$ & $.1 \cdot 19$ & احساس امنيت \\
\hline.$- / \cdot 10$ & $-\cdot /|r|$ & $-\cdot /|r|$ & $* \cdot / 194$ & مادر -فرزندى \\
\hline$-\cdot / \cdot v \Delta$ & $-\cdot / M r$ & $-\cdot / 1 r q$ & .1 .91 & يدر -فرزندى \\
\hline$-\cdot / \cdot \Delta F$ & $-\cdot / l F r$ & $-\cdot / 10$ &.$/ 1 F 9$ & نمره كل جو عاطفى خانواده \\
\hline
\end{tabular}

$* * \mathrm{P}<\cdot / \cdot 1 * \mathrm{P}<\cdot / \cdot \Delta$

معنادارى وجود دارد (ه//P> (P). همجِنين يافته ها نشان داد، بين هديه دادن و مقياس تحمل ارتباط منفى و و

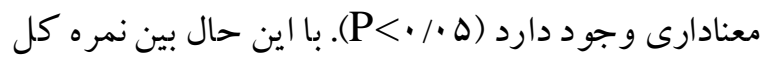
خود تنظيمى هيجانى و جو عاطفى خانواده و زيرمقياس هاى ار تباطى وجود نداشت ( ه • • (P). فرضيه دوم: بين جو عاطفى خانواده و مؤلفه هاى آن و تابآورى رابطه وجود دارد.
همانطور كه در جدول Y مشاهده مى شود، بين تجربههاى

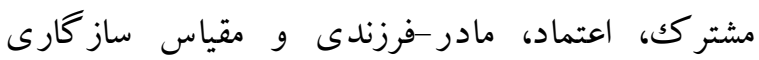

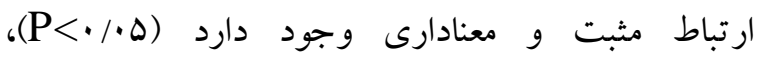
همجنين، بين تائيد كردن و مقياس ساز كارى ارتباط مثبت و معنادارى وجود دارد ( (P</ P). آزمون همبستگى بيرسون نشان داد، بين تجربه مشترك، هديه دادن، احساس امنيت و مقياس ينهانكارى ارتباط منفى و

\begin{tabular}{|c|c|c|c|c|c|c|c|c|c|c|c|}
\hline نمره كل & بدر - & مادر - & احساس & اعتماد & تشويق & هديه & تجربه هاى & تائيد & نوازش & محبت & متغير \\
\hline جانو عاطفى & فرزندى & فرزندى & امنيت & & كردن & دادن & مشترك & كردن & & & \\
\hline
\end{tabular}

\begin{tabular}{|c|c|c|c|c|c|c|c|c|c|c|c|}
\hline$\cdot / \Lambda \vee$ &.$/ 191$ &.$/ 191$ & $\cdot 1 \cdot 14$ & - / TOY &.$/ 19$. & - /IFD & .1199 & $\cdot / 109$ & $-\cdot / \cdot F Y$ & . /1Y4 & تاب آورى \\
\hline * & * & & & 类㫧 & * & & * & & & & \\
\hline
\end{tabular}


$* P<\cdot / . \triangleright$

جهت بررسى بيشينى خودتنظيمى هيجانى و تابآورى بر اساس جو عاطفى خانو اده از تحليل رگرسيون جند متغيره استفاده شد. شاخصهاى مورد بررسى در تحليل

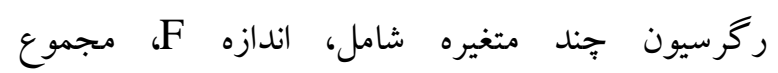
مجذورات، م⿸ ماصلاح شده و سطح معنادارى است. روش به كار گيرى اين آزمون با توجه به مدل General Linear Model
جدول r نشان دهنده ضريب همبستگى بين تاب آورى و جو عاطفى خانواده است. همانطور كه مشاهده مىشود، بين تجربههاى مشترك، تشويق كردن، بدر-فرزندى،

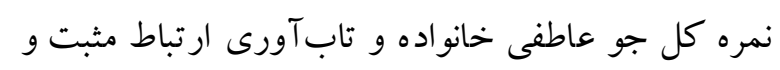

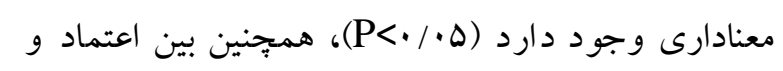

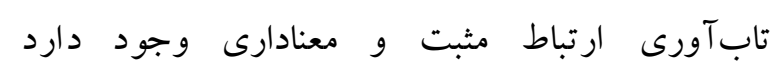
$(\mathrm{P}<\cdot / \cdot 1)$ فرضيه سوم: جو عاطفى خانواده مىتوانل خودتنظيمى هيجانى و تابآ ورى را بيشبينى كند.

\begin{tabular}{|c|c|c|c|c|c|}
\hline $\mathbf{R}^{2}$ & معنادارى & $\mathbf{F}$ & آزادى درجه & مجذورات مجموع & شاخص \\
\hline$\cdot / \cdot r$ &.$/ 81 \mathrm{~V}$ & - /FYY & 1 & $\Delta F / \cdot 1$ & خودتنظيمى \\
\hline ه./. & I.rr & $\Delta / Y q \Lambda$ & 1 & $|r| \cdot / 91$ & تابآورى \\
\hline
\end{tabular}

فرضيه اول: بين جو عاطفى خانواده و مؤ لفه هاى آن و خود تنظيمى هيجانى و مؤ لفه هاى آن رابطه وجود دارد. نتايج نشان داد، بين تجربه هاى مشتركى، اعتماد، مادر -

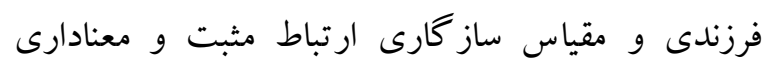
وجود دارد، همجنين، بين تائيد كردن و مقياس ساز گارى

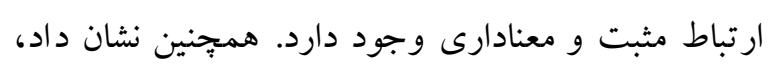
بين تجربه مشتر ك،، هديه دادن، احساس امنيت و مقياس ينهان كارى ارتباط منفى و معنادارى وجود دارد. همجنين

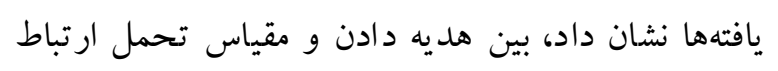

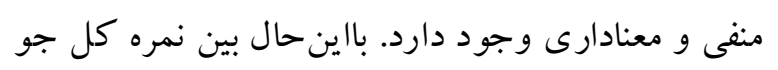
عاطفى خانو اده و نمره كل خودتنظيمى هيجانى ارتباط وني معنادارى وجود نداشت.
همانطور كه در جدول F مشاهده مى شود، جو عاطفى خانواده توانست بم درصد از واريانس تابآورى را در

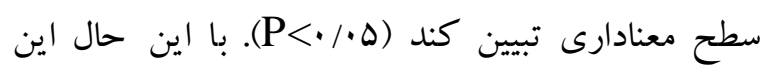
تبيين براى خودتنظيمى هيجانى معنادار نبود؛ بنابراين فرضيه اصلى بثزوهش به صورت نسبى موردحمايت قرار مى كيرد.

\section{بحث} هدف يزوهش حاضر بررسى ارتباط جو عاطفى خانواده بـا

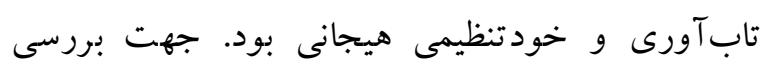
هدف بيزوهش از آزمون همبستخى بيرسون و آزمون

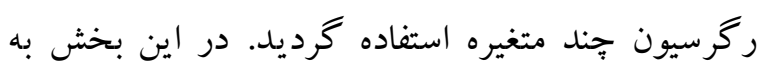
بررسى مجزاى هر سه فرضيه يزوهش برداخته شده است. 
بين والدين و فرزندان وجود داشته باشد نه تنها باعث افزايش اعتماد به نفس در فرزند مى شود بلكه باعث افزايش سازگًارى بالاتر مى شود. ئزوهشها در اين راستا نشان دادهاند كه روابط بين والد-فرزند باعث

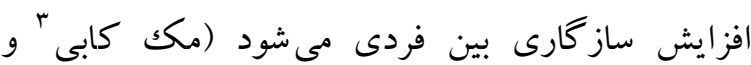

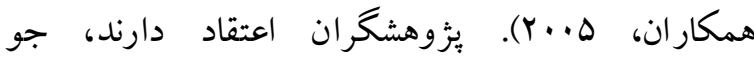
مسالمتآميز و آرامشبخش در خانواده باءث افزايش هيجانات مثبت مىشود و در نتيجه هيجانات مثبت باعث روابط بهتر بين افراد خانواده مىشود. بر همين اساس ساز گارى بالاتر خواهد رفت (وجينيج، هترينكَتون، وجينيج و كلينگمبل ؛ (1991). همجنين، وقتى ياداش دهى و هديه دادن در خانو اده بيشتر شود، باعث كاهش ينهان كارى بين اعضاى خانواده مىشود. تحقيقات نشان دهنده ارتباط بين پِاداش در خانواده و كاهش مشكلات بين فردى است. به عنوان

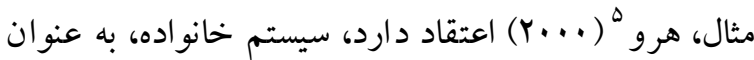
زمينه اى كه در آن افراد وجود دارند، يكك محيط ميانجى براى مراقبت و بِاداش دهى مثبت است. ارزيابى خانو اده،

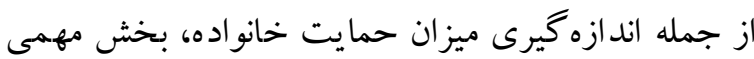
از زندكى يكك فرد به ويزه كودكان و نوجوانان است. توانيى خانو اده براى انطباق در طول زمان، اندازه خيرى توانايى آن در حل مشكلات است. در نتيجه، سيستم خانو اده پِاداش دهنده با مشكلات كمتر مر تبط است.

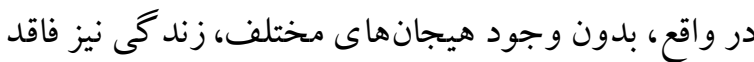
معنى و زيبايى، حس، غنا، شادى و ارتباط با ديخران خو اهد بود. هيجانها مطالبى را درباره نيازها، ناكامىها و حقوق در اختيار افراد قرار مىدهند و موجبات انگيزه

\footnotetext{
${ }^{3}$ McCabe

${ }^{4}$ Vuchinich, Hetherington, Vuchinich, \& Clingempeel

${ }^{5}$ Heru
}

يافتهاى اين فرضيه با بُزوهشهاى، حسينى و سامانى

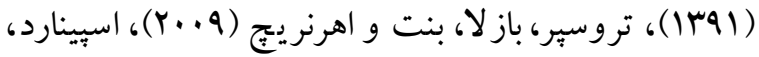

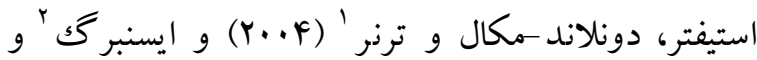

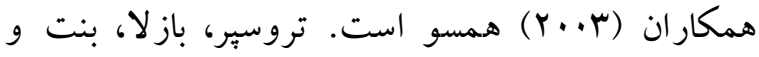
اهرنريج (9. (Y) نشان دادند بين جو خانو ادكى و تنظيم هيجانى ارتباط وجود دارد. همجينين آن ها نتيجه كردند كه مى توان با توجه به جو عاطفى خانو اده و آموزشهاى مهارتهاى خود تنظيمى هيجانى، عملكرد فرد را افزايش داد و همجنين مىتوان از اختلالات روانى همجون اضطراب و استرس بيشخيرى كر د. همجنين، ايسنبر گك و

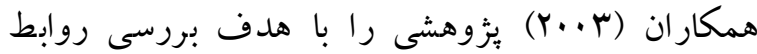
هيجانى خانواده، تنظيم هيجان كودك و و عملكرد اجتماعى آن ها انجام دادند. نمونه مورد بررسى آن ها ها هادي شامل ^•r نفر كود كك بود. يافته ها نشان داد هيجانهاى درون خانو اد گى با خود تنظيمى هيجانى مرتبط است. تفاوت اصلى كه بين يُزوهش هاى بيشين و يُزوهش حاضر وجود دارد، تفاوت در تمر كز بر متغيرهاى يزوهش است. همانطور كه ذكر شد، ئزوهشهاى بيشين با اينكه جو خانوادگى و كاركردهاى خانو ادكى را بررسى كردهاند، اما به طور دقيق ارتباط بين مؤلفههاى جو عاطفى خانواده و خودتنظيمى هيجانى را مورد بررسى قرار نداند. همجنين، ابزارهاى مورد استفاده در بُزوهش هاى بيشين با بزوهش حاضر متفاوت بود. با اين حال، از حيث هدف

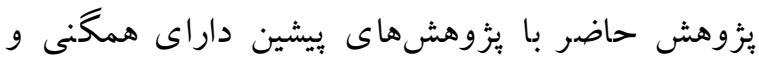

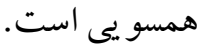
يافتهاى بثزوهش كوياى آن است كه با كسب اعتماد بين فرزند و والدين و ايجاد اشتراكات بين آنها مىتوان باعث افزايش ساز گارى شد. در واقع، زمانى كه اعتماد

${ }^{1}$ Spinrad, Stifter, Donelan-McCall, \& T urner ${ }^{2}$ Eisenberg 
همجنين، يُزوهش هاى قبلى كار كرد خانو اده و اثر آن را در كوتاه مدت مورد بررسى قراردادند، درحالى كه

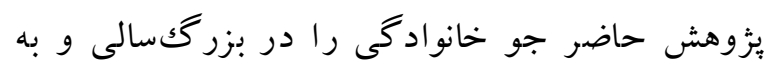
صورت اثر بلند مدت مورد بررسى قرار داد. همجنين، ابزارهايى كه در يزٔوهش هاى بيشين مورد استفاده قرار

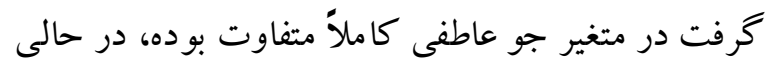
كه اين بززوهش از برسشنامه جو عاطفى خانو اده استفاده كرده است؛ بنابراين تفاوت كلى بين يافته اين بئوهش و

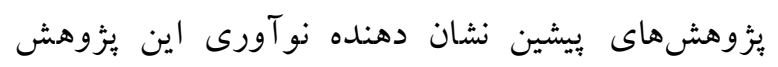
است.

بر اساس شواهد، يُزوهشهاى بيشين نشان دهنده نقش اساسى خانواده و جو عاطفى خانواده در شكل گيرى بهتر تابآورى در جوانان است. خانو اده مىتو اند بين افراد بيوندهاى ناگسستنى ايجاد كند. دلبستخى به بدر و و مادر و همشيرها غالباً بهصورت مادامالعمر است و اين بـاني

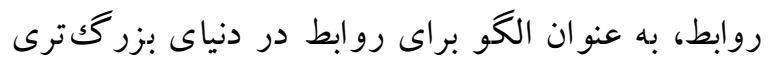

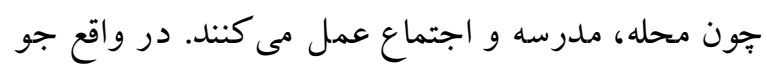

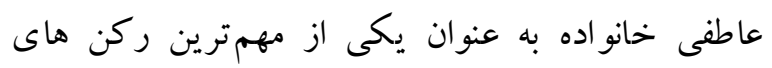
تحول كود كان مى تواند بر جنبه هاى رشدى -تحولى به ويزه افزايش تاب آورى در موقعيتهاى استرس زا نقش بسز ايى داشته باشد؛ يعنى اينكه، فرد ظرفيتى براى مقاومت ورت

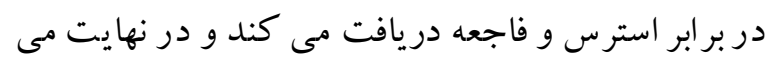
تواند به تنهايى با مشكلات استرس زاى زندگى مقى مقابله

عوامل خانوادگى در برگيرنده بيوستكى و انسجام

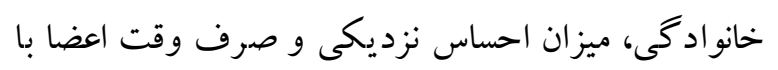
يكديخر، داشتن توقعات بالا و همجنين كمكك به به به نوجو انان براى اجتناب از بروندادهاى منفى است. ورنر

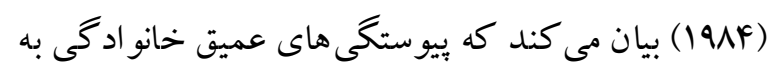

لازم براى تغيير و گريز از موقعيتهاى دشوار را فراهم

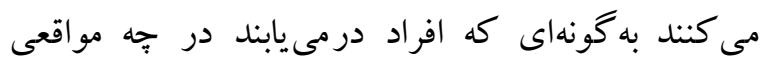
احساس رضايتمندى كنند. درنتيجه، جو خانو ادهاى كه به صورت عاطفى از نوع مثبت را دارا باشد، افراد عضو

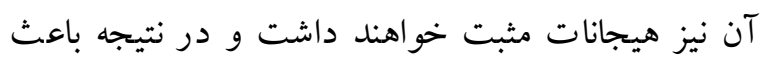
ساز گارى بالاتر و تنظيم هيجانات بهتر خو اهد شد. فرضيه دوم: جو عاطفى خانو اده و مؤلفههاى آن و تاب آورى رابطه وجود دارد. يافتها نشان داد، بين تجربه هاى مشتر كك، تشويق كردن، يدر-فرزندى، نمره كل جو عاطفى خانواده و تابآورى ارتباط مثبت و معنادارى وجود دارد، همجينين بين اعتماد و تابآورى ارتباط مثبت و معنادارى وجود دارد.

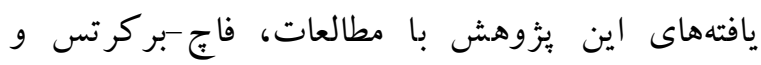

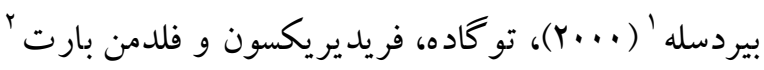

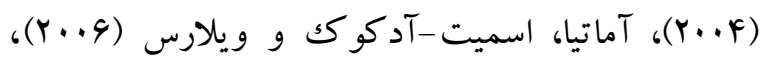

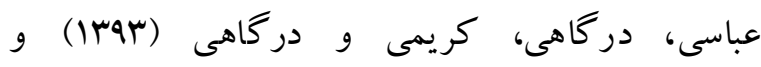
خداجوادى و همكاران (•وبr) همسو است. به عنوان

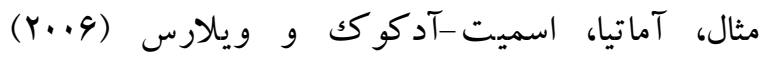
يثووهشى را با هدف بررسى نقاط ضعف و قوت خانواده در تبيين تابآورى در كود كان خانواده انجام دادند. آن

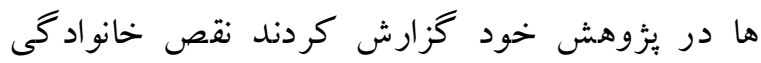
مى تواند تاب آورى را كاهش دهد. در واقع نتايج آن ها كوياى اين بود كه خانواده و جو عاطفى آن مكانى است جهت آماده سازى كودكان براى رو به رو شدن با

$$
\text { جإلشهاى آينده آنها. }
$$

تفاوتى كه بين يثزوهش حاضر و بثزوهشهاى بيشين و جود دارد از حيث ابزار و هدف است. يُزوهشهايى كه اشاره شد عمدتاً بر روى كودكان صورت كرفته است.

\footnotetext{
${ }^{1}$ Focht-Birkerts, \& Beardslee

${ }^{2}$ Tugade, Fredrickson, \& Feldman Barrett
} 
بالاتر بشود باعث خواهد شد كه جوانان كمتر دجار

$$
\text { مشكلات روانشناختى شوند. }
$$

فرضيه سوم: جو عاطفى خانو اده مىتواند خودتنظيمى هيجانى و تاب آورى را ييشبينى كند.

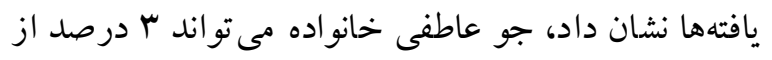
واريانس تابآورى را در سطح معنادارى تبيين كند، با اين حال اين تبيين براى خودتنظيمى هيجانى معنادار نبود. يافتهاى فرضيه اصلى در بخش اينكه جو عاطفى مى تو اند

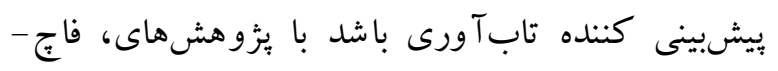

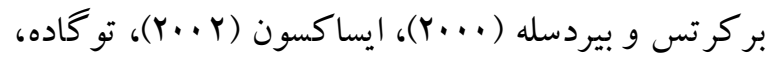

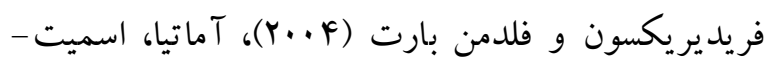

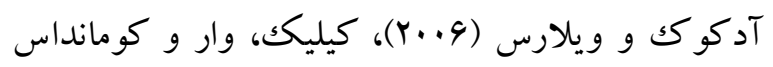

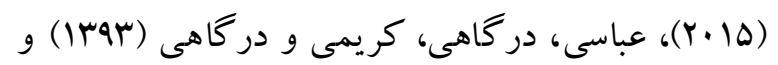
خداجوادى و همكاران ( •وبا1) همسو است. همجينين، در بخش اينكه جو عاطفى مى تواند بيشبينى كننده

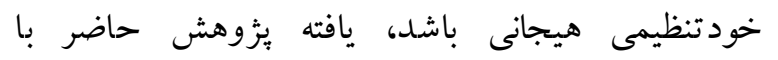

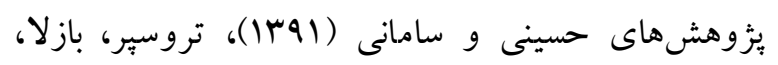
بنت و اهرنريج (Y) (Y.9)، اسيّنارد، استيفتر، دونلاند -مكال

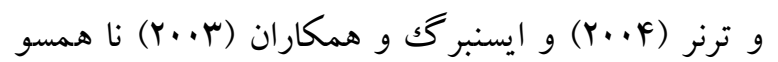

با اين حال تفاوت عمده اى بين يزٔوهش حاضر و يزوهشهاى بيشين از حيث روش و هدف وجود داشته است. اولين تفاوت از حيث هدف است؛ بثزوهش حاضر با هدف بيش بينى تاب آورى و خودتنظيمى هيجانى با توجه به متغير جو عاطفى خانواده صورت كرفت.

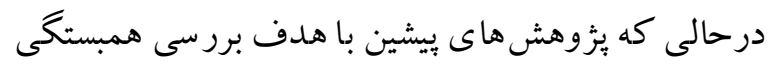
بين اين دو متغير انجام شده بود. همجنين از حيث روش شناسى، تفاوتى كه بين يزوهش حاضر و بيزوهش هاى ياد شده وجود دارد بر اين قرار است كه؛
فرزندان در معرض خطر كمكك مى كند تا باور كنند كه زندگى با معنى است و آن ها بر زندگى خودشان كنترل دارند. اين احساس معنى دارى يكك انخيزه قوى براى كودكان و نوجوانان تاب آور مى شود (به نقل از

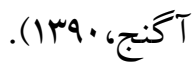

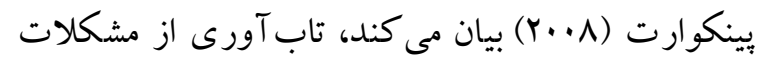
روانشناختى در جوانان و نوجوانان بيشخيرى مى كند و از آنها در برابر تأثيرات روانشناختى حوادث مشكلزا محافظت مى كند (به نقل از حميد، كيخسروانى، باباميرى و دهقانى، اهسا). در واقع، روابط خانوادگى كه از ابتداى تولد تا دوران بزرگكسالى وجود دارد، مى تو اند با ساز كارى و تابآورى در موقعيتهاى مختلف مرتبط

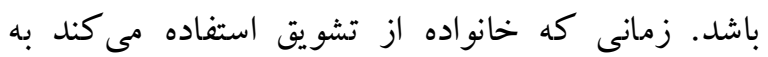
فرزندان و اعضاى خانواده حس مثبت القا مى شود و زمانى كه از تنبيه استفاده مى شود به اعضاى خانو اده حس منفى القا مى گردد؛؛ بنابراين، وقتى در يُك خانواده از تشويق بجاى تنبيه استفاده شود، اعضاى آن خانواده ياد مى گيرند كه در موقعيتهاى سخت و دشوار خود را سرزنش نكنند و تاب آور باشند. در نتيجه، توجه مثبت به

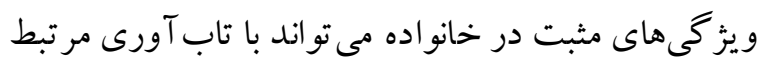

همجنين، تجربيات مشتركى كه بين اعضاى خانواده وجود دارد، مانند باهم غذا خوردن، باهم بيرون رفتن و

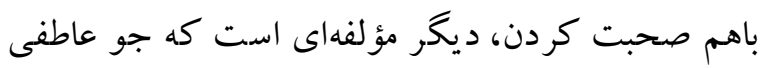
مثبتى را در خانواده مىسازد و باعث مى شود افراد و و اعضاى آن خانواده به دليل تجربه مشتركى، تابآورى بالاترى را كسب كنند؛ بنابراين، با ارتباطى كه بين تابآورى و جو عاطفى خانو اده برقرار است مىتوان نتيجه گرفت كه اين ارتباط هرجه بيشتر باشد و تابـ آورى 
عنوان مثال، سر يكك ميز نشستن زمان خوردن غذا، باعث

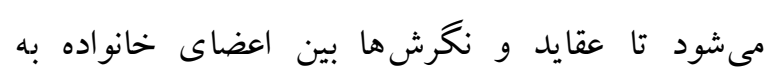

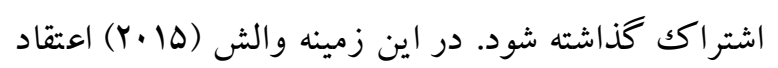

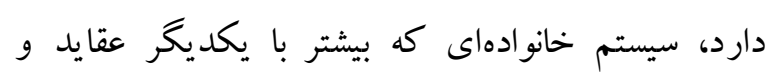

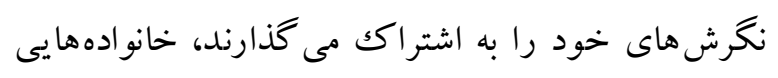

$$
\text { سالم تر هستند. }
$$

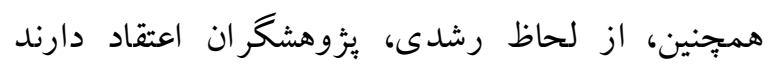

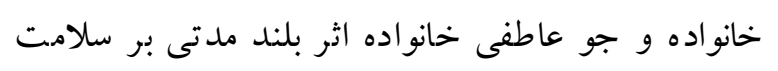
روانى و ويزگ

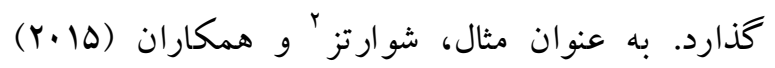
دريافتند، نه تنها خانواده اثر كوتاه مدت بر فرزندان آن دارد بلكه اثر بلند مدتى در دوران هاى بعدى تحول بر

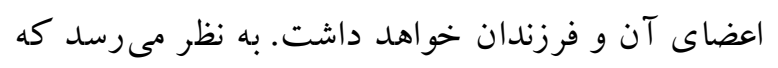
خانوادهاى كه جو عاطفى مثبت ترى داشته باشد يعنى، هديه دادن، محبت كردن، اعتماد كردن در آن خانواده بيشتر باشد، باعث افزايش تحمل و تابآورى در مقابل مشكلات بيش رو همجيون مشكلات اجتماعى، دانشگاهى و تحصيلى براى جو ان خو اهد شد.

\section{نتيجه كيرى}

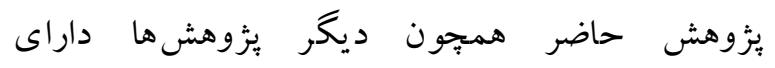

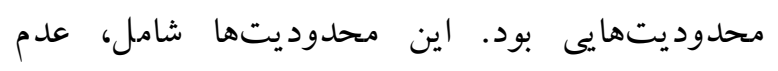
نمونه گيرى تصادفى و جمع آورى داده ها از طريق ابزار خود گزارشى بود كه اين مسئله قابليت اعتماد به نتايج را كاهش مىدهد. در اين راستا، بيشنهاد مىشود كه در يزوهش هاى آتى، نمونه كيرى به صورت تصادفى صورت بخيرد تا استقلال هر فرد رعايت شود. همبنين، ييشنهاد مى شود كه يزوهشى در راستاى بررسى اثرات
يثزوهشهاى بيشين از روش همبستكى و توصيفى استفاده كرده بودند و از نظر ابزارى تفاوت زيادى بين بيزوهش

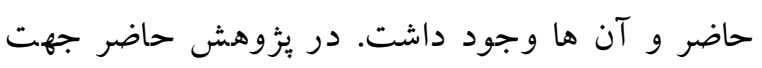
بررسى جو عاطفى خانواده از يرسشنامه هيل برن استفاده

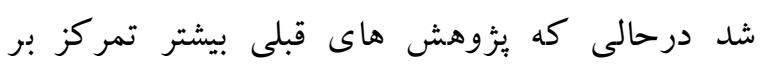
يرسشنامه هاى كار كردى در خانواده داشتند.

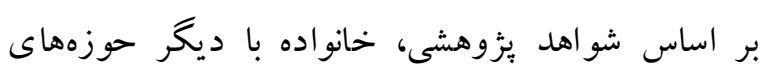

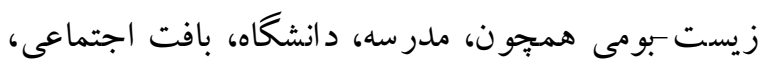
همسالان، در تعامل است. رفتار جوان نيز تحت تأثير تعامل اين حوزهها و سيستم خانو اده قرار مى گيرد. ارتباط اين حوزهها يكك مسير آسيبشناختى براى كاهش تابآورى ايجاد مى كند. اكر خانواده كارآيى لازم راتئ داشته باشد و جو عاطفى مثبتى ايجاد كند، مى تواند بيش بينى كننده افزايش تاب آورى جوان بشود.

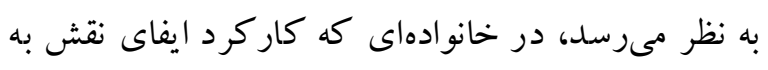

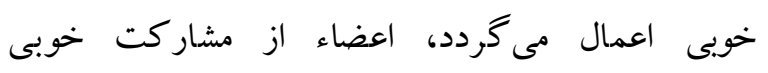
برخوردارند، وقتى به اعضاء مسئوليت ايفاى نقش داده مىشود، بيامى كه داده مى شود اين است كه آنها ارزشمندند و قادرند به عنوان يكك عضو خانو اده در امور مشاركت نمايند. مشاركت باعث مى شود كه اعتماد به نفس و عزت نفس افزايش يابد و در نتيجه باعث رشد تابآورى فرزندان شود. در نتيجه زمانى كه كاركرد خانواده و ايفاى نقشها به درستى و به صورت مثبت باشد، تاب آورى اعضاى خانواده بالا مىرود.

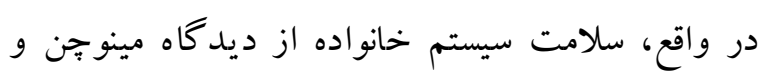

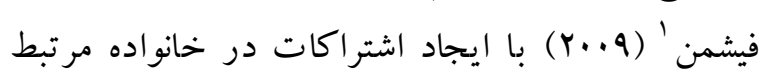
است. زمانى كه اعضاى خانواده اشتراكات زياد ترى داشته باشند، سلامت و ساز كارى آنها بالاتر مىرود. به 
Focht-Birkerts, L., \& Beardslee, W. R. (2000). A chids experience of parental depression: Encouraging relational resilience in families with affective illness. Family process, 39(4), 417-434.

Gross, J. J. (1998). The Emerging Field of Emotion Regulation: An Integrative Review. Reviewe of GeneralPsychology, 2, 3, 271-299.

Gross, J. J. (2002). Emotion regulation: Affective, cognitive, and social consequences. Psychophysiology, 39(3), 281291.

Henu, A. M. (2000). Family functioning, burden, and reward in the caregiving for chronic mental illness. Family, Systems, \& Health, 18(1),91.

Hofmann, S. G., \& Kashdan, T. B. (2010). The affective style questionnaire: development and psychometric properties. Journal of Psychopathology and Behavioral Assessment, 32(2), 255-263.

Hosseini, N., Samani, S. (2012). A Study of the Relationship Between the Family Function Dimensions and Self-Regulation in Children. Joumal of Family Research, 8(31), 305-317. (in Persian)

Houltberg, B. J., Henry, C. S., \& Morris, A. S. (2012). Family interactions, exposure to violence, and emotion regulation: Perceptions of children and early adolescents at risk. Family Relations, 61(2), 283-296.

Khodajavadi, R., Aghabakhshi, H., Rafiei, H., Asghari A., Bayan Memar, A., Abdi Zarin, S. (2011). The Relationship between Family Functioning and Resilience Against Substance Use in Male Students at High Risk High Schools. Social Welfare Quarterly, 11(41), 421-444. (inPersian)

Leahy, R.L., Tirch, D., Napolitano, LA. (2011). Emotion regulation in psychotherapy: A practitioner's guide. Translated by Mansouri Rad, A in 2013. Tehran: Arjmand Publication. (in Persian)

Masten, A. S., Cutuli, J. J., Herbers, J. E, \& Reed, M. G. (2009). 12 Resilience in Development. The Oxford handbook of positive psychology, 117.

$$
\begin{aligned}
& \text { بلند مدت جو عاطفى خانو اده بر تابآورى و خود تنظيمى } \\
& \text { هيجانى در قالب روش طولى انجام شود. به طور كلى } \\
& \text { نتايج يزوهش نشان داد، جو عاطفى خانو اده مى تواند تاب } \\
& \text { آورى را بيش بينى كند، با اين حال اين تبيين براى } \\
& \text { خود تنظيمى هيجانى معنادار نبود. }
\end{aligned}
$$

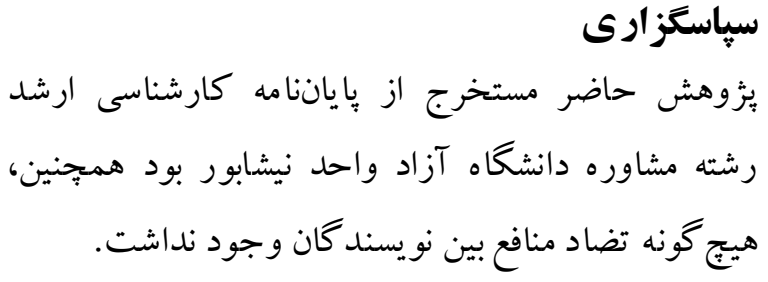

Refrences

Abbasi, M., Dargahi, S., Karimi, K., Dargahi, A. (2015). Family relationship, life quality and Resilience in students with Attention deficit / hyperactivity disorder and Normal Students. Joumal of Health Breeze, 3(1), 12-20. (in Persian)

Agang, N. (2011). Validity and Reliability of the Persian Version of Protective Factors IPFI. Master's Thesis, Islamic Azad University, Marvdasht Branch (in Persian)

Amatea, E., Smith-Adcock, S., \& Villares, E (2006). From Family Deficit to Family Strength: Viewing Families' Contributions to Children s Learning from a Family Resilience Perspective. Professional School Counseling, 9(3), 177-189.

Conner, K. M., \& Davidson, J. R. T. (2003). Development of a new resilience scale: The Conner-Davidson resilience scale (CD-RISC). Depression and Anxiety, 18, 76-82.

Eisenberg, N., Valiente, C., Morris, A. S., Fabes, R. A, Cumberland, A., Reiser, M., ... \& Losoya, S. (2003). Longitudinal relations among parental emotional expressivity, children's regulation, and quality of socioemotional functioning. Developmental psychology, 39(1), 3. 
tailoring approach to adapting parent child

interaction therapy for Mexican Americans. Education and Treatment of Children, 111129.

Minuchin, S., \& Fishman, H. C. (2009). Family therapy techniques. Harvard University Press.

Minuchin, S., Reiter, M. D., \& Borda, C. (2013). The craft of family therapy: Challenging certainties. Routledge.

Najarpoor Ostadi, S, Khadivi, A. (2008). Investigating the relationship between emotional atmosphere of the family and identity, selfconcept and self-esteem of adolescents and youths aged 17-28 in Islamshahr. Educational Science. Education, 1(3), 81-102. (in Persian)

Najmeh, H., Keikhosravani, M., Babamiri, M., Dehghani, M. (2012). The relationship between mental health spiritual intelligence with resiliency in student of Kermanshah University of Medical Sciences. Jentashapir Joumal of Health Research, 3(2), 332-338. (in Persian)

Narimani, M., Abbasi, M. (2009). Investigating the relationship between psychological hardiness and self-esteem with bumout. Joumal of Beyond Management, 2(8), 75-92. (in Persian)

Pölkki, P., Ervast, S. A., \& Huupponen, M. (2005). Coping and resilience of children of a mentally ill parent. Social work in health care, 39(1-2), 151-163.

Rakes, H. A., \& Thompson, R. A. (2006). Family emotional climate, attachment security and young children's emotion knowledge in a high risk sample. British Journal of Developmental Psychology, 24(1), 89-104.

Rashidpoor, H., Tabrizi, M., Shafiabadi, A. (2012). Effectiveness of parental group training with using Satir's family therapy approach on improvement of emotional condition of female students' families in secondary school, district 2 in Kerman. Knowledge \& Research in Applied Psychology, 13(3), 3-11. (in Persian)
McCabe, K. M., Yeh, M., Garland, A. F., Lau, A. S., \& Chavez, G. (2005).The GANA program: A

Samani, S., Jookar, B,m Sahragard, N. (2007). Effects of Resilience on Mental Health and Life Satisfaction. Iraninan Psychiatry and Clinical Psychology, 13(3), 290-295. (in Persian)

Schwart, S. J., Unger, J. B., Zamdoanga, B. L., Cordova, D., Mason, C. A., Huang S., ... \& \& Villamar, J. A. (2015). Developmental trajectories of acculturation: Links with family functioning and mental heath in recentimmigrant hispanic adolescents. Child development, 86(3), 726-748.

Spinrad, T. L., Stifter, C. A., Donelan- McCall, N., \& Turner, L. (2004). Mothers' regulation strategies in response to toddlers' affect: Links to later emotion self- regulation. Social Development, 13(1), 40-55.

Trosper, S. E., Buzzella, B. A., Bennett, S. M., \& Ehrenreich, J. T. (2009). Emotion regulation in youth with emotional disorders: Implications for a unified treatment approach. Clinical Child and Family Psychology Review, 12(3), 234254.

Tugade, M. M., Fredrickson, B. L., \& Feldman Barrett, L. (2004). Psychological resilience and positive emotional granularity: Examining the benefits of positive emotional on coping and health Journal of personality, 72(6), 11611190.

Vuchinich, S., Hetherington, E. M., Vuchinich, R. A., \& Clingempeel, W. G. (1991). Parent-child interaction and gender differences in early adolescents' adaptation to stepfamilies. Developmental Psychology, 27(4),618.

Walsh, F. (2015). Strengthening family resilience. Guilford Publications. 